\title{
Public Information Arrival and Emerging Markets Returns and Volatility
}

\author{
Ali M. Kutan \\ Southern Illinois University-Edwardsville, U.S.A. \\ Tansu Aksoy \\ Southern Illinois University-Edwardsville, U.S.A.
}

\begin{abstract}
Recent findings have heightened the debate about the usefulness of public information in asset markets. Using daily composite and sector index returns, this paper examines the role of public information arrival in an emerging, highinflation economy like Turkey. The findings reveal that real GDP and industrial production announcements have the most important impact on stock returns. Regarding inflation, nominal stock returns increase in response to unfavorable inflation announcements, but only for the financials sector and partially. Market volatility is more sensitive to news about real GNP, balance of trade, tourism and construction. Implications of the findings for market participants are discussed (JEL E6, F3, G2).
\end{abstract}

Keywords: emerging markets, GARCH models, stock market volatility.

\section{Introduction}

Information arrival is a building block of many theoretical models of asset price determination. The mixture of distributions models and recent micro-structure theories rely on information arrival to explain movements in asset returns; e.g., Clark (1973) and Tauchen and Pitts (1983) and O'Hara (1995) and Lyons (2001). The majority of available investigations focuses on selected industrial markets and the most recent evidence from these studies indicates that public information arrival, measured by the publicly released economic and financial data, may not

*We would like to thank two anonymous referees and John Meisel for their excellent comments and suggestions that greatly improved the exposition and the quality of the paper.

(Multinational Finance Journal, 2004, vol. 8, no. 3 \& 4, pp. 227-245)

(C) Multinational Finance Society, a nonprofit corporation. All rights reserved.

DOI: $10.17578 / 8-3 / 4-4$ 
be able to explain the movements in asset prices as well as initial studies suggested. Evidence on the impact of public information on market activity in emerging markets is quite limited.

Recent studies have offered an explanation for the seemingly lack of explanatory power of public information. Cai et al. (2001) emphasize the importance of accounting for calendar and time-varying volatility effects, arguing that distorted estimates are likely to arise otherwise. New models, such as the micro-structure theories, emphasize the role of private information revealed through order flows in affecting asset prices. Ito et al. (1998) provide evidence that private information matters in the Tokyo foreign exchange market. However, Melvin and Yin (2000) and Edmonds and Kutan (2002) report significant public announcement effects in the yen/dollar and Nikkei stock index.

As a result, a debate has emerged about the relative usefulness of public information. Despite the ample evidence for developed markets, empirical evidence on this issue for emerging markets is scant. This is important because the significance of public information on stock prices has implications for the semi-strong form of market efficiency, which states that all public information is reflected in stock prices.

This study also investigates the empirical validity of the Fisher effect. A surprising finding in the financial economics literature is that nominal stock returns and inflation have a negative relationship, implying that the stock market is not a true hedge against inflation and the Fisher effect, which implies a one-to-one direct relationship between asset returns and expected inflation, does not hold. Many studies have offered reasons for this unexpected finding.

Choudhry (2001) argues that the Fisher effect should hold better for high inflation countries because the response of asset prices to inflation news in these economies would be relatively larger. He provides evidence from four high inflation Latin and Central American economies and reports a positive relationship between stock market returns and inflation, suggesting that the Fisher effect indeed holds better for these economies.

This paper investigates how public information, measured by released macroeconomic announcements, affects stock returns and volatility in Turkey. The Turkish economy has been characterized by persistent high inflation rates since the 1970s. Following the sharp increase in world oil prices in 1973-74, the inflation rate started rising, reaching triple-digit levels by 1979 . In response to a weakening economy and a growing level of political instability, major reforms were 
introduced in January 1980. As part of the reforms, the inflation rate declined somewhat during 1981-87, but it reached higher levels again in 1990 due to frequent nominal exchange rate depreciations designed to promote stagnating exports. During the 1990s, the Turkish economy continued to experience high inflation, due to lack of fiscal discipline and an overvalued domestic currency, which finally brought about a major economic crisis in 1994, causing the inflation rate to reach a peak level of $106.3 \%$ in the same year. Although the inflation rate was brought down following the crisis, it has still persisted at moderately high levels in the more recent years, ranging between 55-65\%.

Turkey's inflation experience is distinctive because, while many countries, particularly those in South American countries, have experienced hyperinflation, some have been able to lower inflation to moderate levels and even single-digits in the last decade. Although Turkey never experienced hyperinflation, it has not been able to bring its moderate level of inflation rate down. Instead, inflation has been quite persistent at moderately high and volatile levels for about two decades. At the same time, Turkey has faced an unstable political and financial environment.

Examining the relation between asset returns and inflation in Turkey provides a natural laboratory to test the effectiveness of different financial instruments as a hedge against inflation in an economy with a moderately high and volatile inflation rate. While earlier studies have investigated hyperinflation countries (Choudhry [2001]), this paper examines an economy with moderate but persistent inflation.

Besides employing a composite index, this paper also examines the impact of public information arrival on three sector indices: financials, industrials, and services. This allows us to provide more concrete evidence as to which sector, if any, reacts more significantly to publiclyreleased economic data. A lead-lag model within a GARCH framework is employed to capture the time-varying nature of asset returns in emerging markets; e.g., Beakert and Harvey (1997).

The paper investigates simultaneously the impact of calendar effects and public information on market returns and volatility within an expanded GARCH model, estimated using the maximum likelihood procedure. Earlier studies have tended to focus on stock returns only, ignoring volatility. It is important to study the effects of public information on returns and volatility in a joint framework in order to provide more efficient and reliable estimates.

Specifically, the paper focuses on news regarding the balance of 
trade (BOT), real GNP, industrial production, tourism, the construction sector, and the CPI. Public information arrival may affect market activity by bringing about revisions about investors' expectations about future economic fundamentals, causing portfolio shifts and price volatility as investors reshuffle their portfolio of assets to optimize their investment strategies. A better understanding of the impact of public information on emerging market activity permits both investors and policymakers to make useful inferences about the role played by such information arrival on asset price determination in such markets. Regulators might design policies to improve the transparency of the system if investors do not react to information arrival. It might be undesirable to regulate sectors that respond more favorably to public information arrival because they may act as a source of information for other sectors and may spread information faster.

The rest of the paper is organized as follows. The next section develops the empirical model while section III describes the data sources, provides descriptive statistics, and reports empirical findings. A discussion of the policy implications of the findings is provided in the concluding section.

\section{Methodological Issues}

To examine the effect of public information arrival on stock market returns and volatility, this paper utilizes expanded specifications of the $\operatorname{GARCH}(1,1)$ and $\operatorname{EGARCH}(1,1)$ models. The following general specification of the $\operatorname{GARCH}(1,1)$ is used:

$$
R_{t}=E\left(R_{t} \mid I_{t-1}\right)+\varepsilon_{t}=\alpha_{0}+\sum_{j=1}^{k} \alpha_{j} R_{t-j}+\sum_{s=1}^{m} c_{s} X_{s, t}+\varepsilon_{t}
$$

and

$$
h_{t}=\operatorname{var}\left(R_{t} \mid I_{t-1}\right)=\beta_{0}+\beta_{1} \varepsilon_{t-1}^{2}+\beta_{2} h_{t-1}+\sum_{i=1}^{n} \delta_{i} Z_{i, t},
$$

where $R_{t-s}$, for $s=0,1,2, \ldots$, are nominal stock returns and their lagvalues, $X_{s, t}$, for $s=1,2, \ldots$, are exogenous explanatory variables for the return generating process given by equation $1, I_{t-1}$ is an information set that includes explanatory variables known at time $t-1, \mathcal{E}_{t}$ is an identically and independently distributed (i.i.d.) Gaussian error term, 
$h_{t-s}$, for $s=1,2, \ldots$, are the conditional variances of returns and their lagvalues, $\varepsilon_{t-s}^{2}$, for $s=1,2, \ldots$, are past squared error terms used as proxies for volatility shocks and $Z_{i, t}$ are exogenous explanatory variables for the conditional variances, given by equation 2 .

It has been frequently observed that negative shocks in a financial market have a different impact on conditional volatility than positive shocks of the same magnitude. The latter effect can be modeled using the following expansion of the conditional variance equation,

$$
h_{t}=\beta_{0}+\beta_{1} \varepsilon_{t-1}^{2}+\beta_{2} h_{t-1}+\gamma D_{t-1} \varepsilon_{t-1}^{2}+\sum_{i=1}^{n} \delta_{i} Z_{i, t}
$$

where the dummy variable $D_{t-1}$ is equal to one when $\mathcal{E}_{t-1}$ is less than zero, and zero otherwise. In this model, good news $\left(\varepsilon_{t-1}<0\right)$ and bad news $\left(\varepsilon_{t-1}>0\right)$ have differential effects on the conditional variance. Bad news has an impact of $\beta_{1}$, while good news has an impact of $\left(\beta_{1}+\gamma\right)$. If $\gamma$ is statistically significantly different from zero, the news impact is asymmetric. The above model is commonly known as TARCH.

The specification for the conditional variance for the expanded EGARCH $(1,1)$ used in this paper is: ${ }^{1}$

$$
\log \left(h_{t}\right)=\beta_{0}+\beta_{1}\left|u_{t-1}\right|+\beta_{2} \log \left(h_{t-1}\right)+\gamma u_{t-1}+\sum_{i=1}^{n} \delta_{i} Z_{i, t}
$$

where $u_{t}=\varepsilon_{t} / \sqrt{h_{t}}$ is an i.i.d. standardized residual. The logarithmic specification of the conditional variance implies that the leverage effect is exponential. Differential effects in this model can be tested by the hypothesis that $\gamma<0$. If $\gamma$ is not equal to zero, the news impact is asymmetric. The coefficients $\delta_{i}$, for $i=1,2, \ldots$ measure the impact of the exogenous variables on the logarithm conditional variance of returns; i.e., positive signs imply a positive relationship and vice versa.

Note that the conditional mean and conditional variance equations for all three GARCH type models include exogenous variables that have a likely impact on the return and volatility generating processes in the Turkish stock market. These include macroeconomic and financial variables as well as indicator variables accounting for relevant announcements, economic, political and other events.

1. The conditional mean specification for EGARH is the same as that of equation 1. 
Indicator variables are constructed in two ways, that is, to examine the differential effects of negative (bad) and positive (good) news on nominal stock returns. Specifically, releases indicating a decline in the BOT deficit and inflation, or an increase in the real GNP, industrial production, and the number of tourists visiting Turkey are treated as good news while the opposite is viewed as bad news.

To differentiate between good and bad news, an expectation formation process based on the last period's observed data is employed. For example, if observed inflation rate today is higher than last period's inflation rate, it is treated as bad news. The construction sector activities were declining throughout the sample period. Therefore, all news on this sector is viewed as bad news.

Data for each particular news category are constructed as a dummy variable, taking the value of one when there is an announcement and zero otherwise. A world return index and the day-of-the-week effect dummies are also included in the estimations. As a proxy for global stock market developments, we employ the S\&P 500 returns. To adjust for differences in time zones, world returns are lagged by one period

Finally, the paper accounts for the impact of recent financial and supply side shocks, including the recent Asian and Russian crises, the U.S. market crash of October 1997, and the banking crisis in Turkey in 2000, and the devastating earthquake in August 1999. These are included as $(0,1)$ dummy variables in estimations as follows: The South-Asian crisis (from August 1 through September 1, 1997), the U.S. financial market crash (October 27, 1997), Russian economic crisis (from August 3 through September 1, 1998), and the banking crisis (from November 20 through November 21, 2000). The first trading day (August 26, 1999) following the earthquake is used to account for the impact of the August 17th earthquake on stock market activity.

\section{Empirical Results}

\section{A. Data}

The data includes daily closing prices for the composite, financial, industrial and service stock market indices of the Istanbul Stock Exchange from January 2, 1996 to February 16, 2001, except for services for which data are available starting on January 2, 1997. The ISE composite (National-100) index is composed of national market 
TABLE 1. Descriptive Statistics for Stock Market Returns

\begin{tabular}{lccrrr}
\hline & Composite & Financials & Industrials & Services & World \\
\hline Mean & 0.2593 & 0.3117 & 0.2217 & 0.1755 & 0.5881 \\
St. dev. & 3.3550 & 3.7293 & 3.0681 & 3.5062 & 1.1739 \\
Skewness & 0.0990 & 0.0841 & -0.0528 & 0.2045 & -0.2856 \\
Kurtosis & 6.0992 & 5.7543 & 6.6930 & 5.6498 & 6.6579 \\
Jarque-Bera & 506.3170 & 399.7620 & 716.5768 & 303.4136 & 719.5972 \\
No. obs. & 1,260 & 1,260 & 1,260 & 1,013 & 1,260 \\
\hline
\end{tabular}

Note: Returns are computed by log-differencing stock price index, multiplied by 100 .

companies, except investment trusts. The stocks in the index are selected on the basis of pre-determined criteria directed for the companies to be included in the indices as well as in the consideration of their ability to represent relevant sectors. The financials index is composed of banks, insurance, leasing and factoring companies, and holding and investment companies, while the industrials index is composed of food, beverage, textile, leather, wood, paper, printing, chemical, petroleum, plastic, non-metal mineral products, basic metal, metal products and machinery companies. The services index includes electricity, transportation, tourism, wholesale and retail trade companies. The stock market data are obtained from the website of the Central Bank of Republic of Turkey. The S\&P 500 index is downloaded from Yahoo finance.

Released dates for the macroeconomic data are available from the website of the State Institute of Statistics (SIS) of Turkey. All news releases are monthly, except GNP and construction, which are quarterly. According to the SIS, all news is generally announced in late afternoon except the CPI, which tends to be announced early in the morning. Investors may observe the released information with a lag due to using a variety of media resources. They may also act the day before based on expectations about a particular release. To capture these effects, a leadlag model is employed in this study.

\section{B. Descriptive Statistics}

Table 1 reports the descriptive statistics for returns. The financials index returns, computed using the logarithmic difference of two consecutive price levels, are relatively higher than the common stock returns and 
other sector returns. Although domestic returns are much higher than their world counterpart, standard errors are proportionally larger, too, indicating that the Turkish market is relatively riskier. The results for kurtosis and skewness indicate the non-normality of returns, which is also supported by the reported Jarque-Bera statistics. To account for the non-normality of the returns, the robust standard errors developed by Bollerslev and Wooldridge (1992) are employed in the estimations.

\section{Information Arrival and Returns and Volatility}

As a preliminary to a larger set of estimations, it was first investigated which GARCH model, reviewed in the previous section, best represents the data generating process for stock returns. In all cases the $\operatorname{EGARCH}(1,1)$ model appeared to be a relatively better fit for modeling stock returns in Turkey and is therefore employed in the study.

Table 2 presents the results for the impact of public information on stock market activity. First, the findings for the mean equation (panel A) are reported, followed by those for the conditional volatility (panel B). All estimations include up to ten lagged returns. We found significant autocorrelation in all the returns, except services, and the industrials sector returns exhibit the highest degree of correlation. These results are not reported for space considerations, but they are available upon request.

\section{Mean Equation Results}

Starting with the impact of good inflation news (CPI_G) on stock returns, we find that on the announcement date of the CPI, there is an increase in the industrials sector returns by $0.72 \%$, while there is no change in returns the day before the announcement. Recall good news means that observed inflation today is lower than last month's inflation. There is significant response to good CPI news the day after the announcement, however, except for services. The returns increase by $0.64 \%, 0.92 \%$, and $0.58 \%$ for the composite, financials and industrial sectors, respectively. One reason why there is an increase in nominal stock returns after the announcement is that the released figures may not be as good as expected. Second reason is the substitution effect. A decline in the inflation rate may signal lower nominal interest rates, causing a decline in demand for bonds, and hence increases the demand for shares. 
Regarding negative inflation news (CPI_B), on the announcement date, there is an increase in returns only in the financials sector returns equal to about $0.94 \%$. There is no significant response to bad CPI news the day before or after the announcement. Given that inflation announcements are released on a monthly basis, the increase of $0.94 \%$ on the announcement date translates into an increase of about $11.3 \%$ per annum in nominal stock returns for the financials sector. However, the average annual inflation rate based on the IMF data during the same sample period was more than $70 \%$, which is much larger than the suggested increase in nominal stock returns for the financial sector. Thus, this evidence suggests that the financial sector provided the best hedge in the Istanbul stock market during the sample period, but it was at best a partial hedge against inflation. These results support the findings of Cagan (1974) who reports a positive link between stock returns and inflation rate for several countries during the 1939-69 period. It is also consistent with a recent study by Choudhry (2001) who finds that nominal stock returns react more to inflation in high inflation countries in Latin America than low inflation, industrial countries. However, the evidence about the Fisher effect for Turkey is not as significant as the evidence reported in Choudhry (2001) for Latin American economies.

Turning to the impact of real sector announcements, good news about the balance of trade (BOT_G) affects the industrials and services sectors, but only on the day of the announcement. Because these sectors are more trade-oriented, this result is expected. Negative balance of trade (BOT_B) announcements affect only the services sector and only the day before the announcement. This impact is positive, however, suggesting that investors were optimistic about the news.

Good GNP news before the announcement date has no influence on any returns. However, the composite and financials sector returns increase by $0.63 \%$ and $0.71 \%$, respectively, on the announcement date. The day after the announcement date, there is an increase all the returns, except for services. The biggest impact, $1.73 \%$, is on the financials index returns.

Regarding negative GNP news, there is no change in any of the returns on the day of the announcement, but the day before the announcement there is an increase in all the returns, indicating some optimism about the news. Financial sector returns increase the next day as well.

Positive industrial production (IP_G) news has no impact on any of 
TABLE 2. Impact of Public Information: EGARCH Specification.

\begin{tabular}{|c|c|c|c|c|}
\hline Variables & Composite & Financials & Industrials & Services \\
\hline \multicolumn{5}{|c|}{ A: Conditional mean of returns } \\
\hline \multirow[t]{2}{*}{ Constant } & -0.2429 & -0.1843 & -0.3115 & -0.4111 \\
\hline & 0.11 & 0.26 & $0.03 *$ & $0.03 *$ \\
\hline \multirow{2}{*}{ CPI_G } & 0.3864 & 1.1023 & -0.1023 & 0.1823 \\
\hline & 0.43 & 0.15 & 0.26 & 0.65 \\
\hline \multirow[t]{2}{*}{ CPI_G } & 0.5423 & 0.4734 & 0.7250 & 0.3612 \\
\hline & 0.14 & 0.32 & $0.03 *$ & 0.47 \\
\hline \multirow{2}{*}{ CPI_G } & 0.6450 & 0.9223 & 0.5860 & 0.5366 \\
\hline & $0.10 * *$ & $0.01 *$ & $0.04 *$ & 0.41 \\
\hline \multirow[t]{2}{*}{ CPI_B ${ }_{\text {LAG }}$} & 0.3256 & 0.1543 & 0.5212 & -0.6566 \\
\hline & 0.41 & 0.76 & 0.12 & 0.18 \\
\hline \multirow[t]{2}{*}{ CPI_B } & 0.3744 & 0.9468 & 0.3111 & -0.3389 \\
\hline & 0.38 & $0.06 * *$ & 0.40 & 0.60 \\
\hline \multirow[t]{2}{*}{ CPI_B } & -0.2101 & 0.1234 & -0.3023 & 0.4012 \\
\hline & 0.58 & 0.76 & 0.36 & 0.48 \\
\hline \multirow[t]{2}{*}{ BOT_G $\mathrm{G}_{\mathrm{LAG}}$} & 0.2306 & 0.3911 & 0.1198 & 0.2933 \\
\hline & 0.75 & 0.50 & 0.88 & 0.61 \\
\hline \multirow[t]{2}{*}{ BOT_G } & 0.4111 & 0.3878 & 0.9586 & 1.6400 \\
\hline & 0.35 & 0.45 & $0.04 *$ & $0.00 *$ \\
\hline \multirow[t]{2}{*}{ BOT_G } & 0.7001 & 0.2212 & 0.3557 & 0.0367 \\
\hline & 0.12 & 0.75 & 0.46 & 0.95 \\
\hline \multirow{2}{*}{ BOT_B $_{\text {LAG }}$} & 0.3111 & 0.3012 & 0.0880 & 0.1489 \\
\hline & 0.53 & 0.44 & 0.75 & 0.72 \\
\hline \multirow[t]{2}{*}{ BOT_B } & 0.4900 & 0.4745 & 0.1905 & -0.1712 \\
\hline & 0.24 & 0.26 & 0.52 & 0.62 \\
\hline \multirow{2}{*}{ BOT_B } & 0.3742 & -0.1071 & 0.3557 & 0.8410 \\
\hline & 0.22 & 0.81 & 0.46 & $0.00^{*}$ \\
\hline \multirow[t]{2}{*}{ GNP_G $\mathrm{L}_{\mathrm{LAG}}$} & 0.5201 & -0.0398 & 0.3583 & 0.6594 \\
\hline & 0.20 & 0.94 & 0.26 & 0.33 \\
\hline \multirow[t]{2}{*}{ GNP_G } & 0.6376 & 0.7120 & 0.0968 & 0.1833 \\
\hline & $0.10 * *$ & $0.06 * *$ & 0.77 & 0.71 \\
\hline \multirow[t]{2}{*}{ GNP_G LEAD $_{\text {L }}$} & 1.0662 & 1.7300 & 1.1591 & -0.1656 \\
\hline & $0.03^{*}$ & $0.00 *$ & $0.00^{*}$ & 0.80 \\
\hline \multirow[t]{2}{*}{ GNP_B LAG $_{\text {La }}$} & 3.0012 & 2.5528 & 2.7537 & 4.5401 \\
\hline & $0.00^{*}$ & $0.00 *$ & $0.00 *$ & $0.00 *$ \\
\hline \multirow[t]{2}{*}{ GNP_B } & -0.7184 & -0.9445 & 0.7111 & -1.2456 \\
\hline & 0.68 & 0.62 & 0.55 & 0.54 \\
\hline \multirow{2}{*}{ GNP_B } & -0.5655 & 1.7300 & 0.9228 & -0.3101 \\
\hline & 0.73 & $0.00 *$ & 0.66 & 0.86 \\
\hline \multirow[t]{2}{*}{ IP_G ${ }_{\text {LAG }}$} & 0.0761 & -0.0310 & 0.1715 & 0.2609 \\
\hline & 0.78 & 0.94 & 0.54 & 0.54 \\
\hline \multirow[t]{2}{*}{ IP_G } & -0.3911 & -0.7741 & -0.2078 & -0.4443 \\
\hline & 0.22 & 0.14 & 0.48 & 0.37 \\
\hline \multirow[t]{2}{*}{ IP_G $\mathrm{G}_{\mathrm{LEAD}}$} & 0.3856 & -0.0711 & 0.3547 & -0.1045 \\
\hline & 0.23 & 0.86 & 0.25 & 0.83 \\
\hline
\end{tabular}

(Continued) 
TABLE 2. (Continued)

\begin{tabular}{|c|c|c|c|c|}
\hline Variables & Composite & Financials & Industrials & Services \\
\hline \multicolumn{5}{|c|}{ A: Conditional mean returns equation (cont.) } \\
\hline \multirow[t]{2}{*}{ IP_B LAG $_{2}$} & 1.4278 & 1.6171 & 1.8075 & 0.9582 \\
\hline & $0.06 * *$ & $0.06 * *$ & $0.02 *$ & 0.25 \\
\hline \multirow[t]{2}{*}{ IP_B } & 0.8512 & 1.2303 & 0.6334 & 0.8878 \\
\hline & 0.16 & $0.02 *$ & 0.30 & 0.11 \\
\hline \multirow[t]{2}{*}{ IP_B LEAD $_{1}$} & -1.9768 & -2.0803 & -1.7260 & -1.9404 \\
\hline & $0.00 *$ & $0.01 *$ & $0.00 *$ & $0.01 *$ \\
\hline \multirow[t]{2}{*}{$\mathrm{CONST}_{\mathrm{LAG}}$} & -0.7945 & -0.3222 & -0.3700 & -0.6972 \\
\hline & $0.05 *$ & 0.52 & 0.41 & 0.30 \\
\hline \multirow[t]{2}{*}{ CONST } & 0.1312 & 0.4600 & 0.1012 & 0.1145 \\
\hline & 0.73 & 0.23 & 0.79 & 0.77 \\
\hline \multirow[t]{2}{*}{$\mathrm{CONST}_{\text {LEAD }}$} & -0.7546 & -1.3393 & -0.7273 & -1.1441 \\
\hline & $0.00 *$ & $0.02 *$ & $0.02 *$ & $0.01 *$ \\
\hline \multirow[t]{2}{*}{ TOUR_G } & 0.8861 & 1.1298 & 0.68765 & 1.8411 \\
\hline & $0.00^{*}$ & $0.00^{*}$ & $0.01 *$ & $0.00 *$ \\
\hline \multirow[t]{2}{*}{ TOUR_G } & 0.2212 & 0.6086 & 0.0523 & -0.1209 \\
\hline & 0.53 & 0.16 & 0.89 & 0.78 \\
\hline \multirow[t]{2}{*}{ TOUR_G } & -0.3634 & -0.2575 & -0.2217 & 0.5010 \\
\hline & 0.30 & 0.55 & 0.46 & 0.25 \\
\hline \multirow{2}{*}{ TOUR_B } & -0.4078 & -0.4553 & 0.7337 & 0.3100 \\
\hline & 0.43 & 0.35 & $0.08 * *$ & 0.44 \\
\hline \multirow[t]{2}{*}{ TOUR_B } & -0.0134 & -0.1877 & 0.0913 & 0.2745 \\
\hline & 0.99 & 0.74 & 0.82 & 0.54 \\
\hline \multirow[t]{2}{*}{ TOUR_B LEAD $_{\text {L }}$} & 0.1676 & 0.1332 & 0.2289 & 0.5355 \\
\hline & 0.70 & 0.77 & 0.46 & 0.38 \\
\hline \multirow[t]{2}{*}{ World return } & 0.3792 & 0.3636 & 0.2957 & 0.3832 \\
\hline & $0.00^{*}$ & $0.00 *$ & $0.00^{*}$ & $0.00 *$ \\
\hline \multirow[t]{2}{*}{ Asian Crisis } & 0.0689 & 0.2641 & 0.0287 & 0.2017 \\
\hline & 0.78 & 0.30 & 0.91 & 0.42 \\
\hline \multirow[t]{2}{*}{ US Crash } & -4.7767 & -5.0330 & -6.2741 & -4.3034 \\
\hline & $0.00 *$ & $0.00 *$ & $0.00^{*}$ & $0.00^{*}$ \\
\hline \multirow[t]{2}{*}{ Russian Crisis } & -0.8472 & -0.8314 & -1.2447 & -1.5667 \\
\hline & $0.10 * *$ & 0.22 & $0.01 *$ & $0.05 *$ \\
\hline \multirow[t]{2}{*}{ Earthquake } & -11.4556 & -13.8906 & -8.6222 & -3.9411 \\
\hline & $0.00^{*}$ & $0.00 *$ & $0.00 *$ & $0.00^{*}$ \\
\hline \multirow[t]{2}{*}{ Bank Crisis } & -0.8389 & -3.2696 & -4.4922 & -1.9000 \\
\hline & 0.16 & $0.03 *$ & $0.00 *$ & 0.58 \\
\hline \multirow[t]{2}{*}{ Monday } & -0.7366 & -0.9362 & -0.4815 & -0.5834 \\
\hline & $0.00 *$ & $0.00 *$ & $0.02 *$ & $0.04 *$ \\
\hline \multirow[t]{2}{*}{ Tuesday } & -0.3982 & -0.3458 & -0.2077 & 0.0757 \\
\hline & $0.04 *$ & 0.11 & 0.27 & 0.76 \\
\hline \multirow[t]{2}{*}{ Thursday } & 0.4021 & 0.4275 & 0.5250 & 0.5276 \\
\hline & $0.04 *$ & $0.08 *$ & $0.00 *$ & $0.04 *$ \\
\hline \multirow[t]{2}{*}{ Friday } & 0.0882 & -0.1509 & 0.3131 & 0.4389 \\
\hline & 0.24 & 0.50 & $0.08 * *$ & $0.07 * *$ \\
\hline
\end{tabular}

(Continued) 
TABLE 2. (Continued)

\begin{tabular}{|c|c|c|c|c|}
\hline Variables & Composite & Financials & Industrials & Services \\
\hline \multicolumn{5}{|c|}{ B: Conditional variance of returns } \\
\hline \multirow{2}{*}{$\beta_{0}$} & 0.1012 & -0.0667 & 0.3157 & -0.0999 \\
\hline & 0.55 & 0.70 & $0.07 * *$ & 0.60 \\
\hline \multirow{2}{*}{$\beta_{1}$} & 0.9400 & 0.9399 & 0.9062 & 0.9456 \\
\hline & $0.00 *$ & $0.00 *$ & $0.00 *$ & $0.00 *$ \\
\hline \multirow{2}{*}{$\beta_{2}$} & 0.2401 & 0.2786 & 0.3335 & 0.2401 \\
\hline & $0.00 *$ & $0.00 *$ & $0.00 *$ & $0.00 *$ \\
\hline \multirow[t]{2}{*}{$\gamma$} & -0.1343 & -0.1155 & -0.1441 & -0.0701 \\
\hline & $0.00^{*}$ & $0.00^{*}$ & $0.00^{*}$ & $0.02 *$ \\
\hline \multirow[t]{2}{*}{ Volume } & 0.0201 & 0.0142 & 0.0137 & 0.0155 \\
\hline & $0.00^{*}$ & $0.00^{*}$ & $0.00 *$ & $0.00^{*}$ \\
\hline \multirow[t]{2}{*}{$\mathrm{CPI}_{\mathrm{LAG}}$} & -0.1123 & 0.1749 & -0.3636 & -0.1366 \\
\hline & 0.63 & 0.42 & 0.11 & 0.57 \\
\hline \multirow[t]{2}{*}{ CPI } & 0.0878 & 0.2167 & 0.1883 & 0.3589 \\
\hline & 0.75 & 0.35 & 0.46 & 0.27 \\
\hline \multirow[t]{2}{*}{$\mathrm{CPI}_{\mathrm{LEAD}}$} & 0.1899 & -0.0899 & 0.1251 & -0.2266 \\
\hline & 0.43 & 0.63 & 0.53 & 0.40 \\
\hline \multirow[t]{2}{*}{$\mathrm{BOT}_{\mathrm{LAG}}$} & 0.5301 & 0.4005 & 0.7045 & 0.3694 \\
\hline & $0.01 *$ & $0.04 *$ & $0.00^{*}$ & $0.04 *$ \\
\hline \multirow[t]{2}{*}{ BOT } & 0.1645 & -0.0123 & -0.0766 & 0.2598 \\
\hline & 0.55 & 0.94 & 0.77 & 0.44 \\
\hline \multirow[t]{2}{*}{$\mathrm{BOT}_{\text {LEAD }}$} & -0.3723 & -0.1645 & -0.2447 & -0.6810 \\
\hline & 0.14 & 0.44 & 0.35 & $0.04 *$ \\
\hline \multirow[t]{2}{*}{$\mathrm{GNP}_{\mathrm{LAG}}$} & 0.1298 & 0.0509 & 0.1555 & 0.4966 \\
\hline & 0.67 & 0.84 & 0.57 & 0.20 \\
\hline \multirow[t]{2}{*}{ GNP } & -0.63 & -0.5804 & -0.8338 & -0.3645 \\
\hline & $0.07 * *$ & $0.07 * *$ & $0.01 *$ & 0.38 \\
\hline \multirow{2}{*}{$\mathrm{GNP}_{\text {LEAD }}$} & 0.32 & 0.0394 & 0.1612 & -0.3024 \\
\hline & 0.30 & 0.92 & 0.57 & 0.45 \\
\hline \multirow{2}{*}{$\mathrm{IP}_{\mathrm{LAG}}$} & -0.12 & 0.0376 & -0.0755 & -0.1067 \\
\hline & 0.54 & 0.88 & 0.69 & 0.64 \\
\hline \multirow[t]{2}{*}{ IP } & -0.21 & 0.2055 & 0.0211 & -0.0847 \\
\hline & 0.42 & 0.60 & 0.91 & 0.73 \\
\hline \multirow[t]{2}{*}{$\mathrm{IP}_{\mathrm{LEAD}}$} & 0.21 & -0.0666 & -0.0833 & 0.0583 \\
\hline & 0.48 & 0.86 & 0.67 & 0.83 \\
\hline \multirow[t]{2}{*}{$\mathrm{CONST}_{\mathrm{LAG}}$} & -0.60 & 0.6715 & 0.6666 & -0.5136 \\
\hline & 0.11 & $0.08 * *$ & $0.01 *$ & 0.12 \\
\hline \multirow[t]{2}{*}{ CONST } & -0.02 & -0.4166 & 0.2406 & -0.6156 \\
\hline & 0.95 & 0.30 & 0.53 & 0.19 \\
\hline \multirow[t]{2}{*}{$\mathrm{CONST}_{\text {LEAD }}$} & 0.54 & -0.1292 & -0.9082 & 1.2932 \\
\hline & 0.14 & 0.66 & $0.04 *$ & $0.01 *$ \\
\hline \multirow[t]{2}{*}{ TOUR $_{\text {LAG }}$} & -0.16 & -0.3803 & -0.1623 & 0.2483 \\
\hline & 0.51 & $0.03 *$ & 0.35 & 0.41 \\
\hline \multirow[t]{2}{*}{ TOUR } & 0.16 & 0.0688 & 0.0119 & 0.2477 \\
\hline & 0.58 & 0.80 & 0.96 & 0.40 \\
\hline TOUR $_{\text {LEAD }}$ & -0.24 & -0.0277 & -0.0123 & -0.5846 \\
\hline & 0.22 & 0.89 & 0.98 & $0.00 *$ \\
\hline
\end{tabular}


TABLE 2. (Continued)

\begin{tabular}{lcccc}
\hline Variables & Composite & Financials & Industrials & Services \\
\hline B: Conditional & variance of returns & (cont.) & & \\
Monday & 0.42 & 0.5805 & 0.0533 & 0.4753 \\
& $0.06^{* *}$ & $0.00^{*}$ & 0.84 & $0.04^{*}$ \\
Tuesday & -0.57 & -0.4586 & -0.7751 & -0.2746 \\
& $0.02^{*}$ & $0.05^{*}$ & $0.00^{*}$ & 0.37 \\
Thursday & -0.51 & -0.2843 & -0.7190 & -0.3484 \\
& 0.19 & 0.40 & $0.05^{*}$ & 0.32 \\
Friday & -0.26 & -0.0167 & -0.5555 & -0.2634 \\
& 0.26 & 0.98 & $0.02 *$ & 0.28 \\
C. Diagnostic tests & & & \\
Q(10) & 4.5211 & 8.1003 & 6.8944 & 13.0423 \\
& 0.92 & 0.62 & 0.74 & 0.22 \\
$Q^{2}(10)$ & 3.0745 & 2.3822 & 4.3628 & 5.1719 \\
& 0.98 & 0.99 & 0.93 & 0.88 \\
Log-L & $-2,997.6$ & $-3,189.1$ & $-2,881.4$ & $2,519.3$ \\
\hline
\end{tabular}

Note: Estimates are based on an $\operatorname{EGARCH}(1,1)$ model specification; see equations 1 and 4. Estimated coefficients are reported first, followed by $p$-values under the coefficients. $Q(10)$ statistic is for serial correlation and $Q^{2}(10)$ for ARCH effects. LOG-L is the sample log-likelihood function value.*statistically significant at the $5 \%$ level. **statistically significant at the $10 \%$ level.

the returns, indicating that investors discounted the information contained in the positive news correctly. Negative industrial production (IP_B) news the day before the announcement is associated with lower returns for all shares. On the day of the announcement, there is an increase in the financials sector returns. Negative IP news causes an increase in all sector returns the day after the announcement, except for services, suggesting some overreaction to the initial news.

Observed significant stock price reactions the day before the announcement might be due to leakage of information, especially to privileged traders. Although this issue should not be disregarded entirely, it was probably more relevant during the early years of the stock market, but certainly not in recent years during the sample period. One plausible explanation is that the significant reaction the day before the announcement reflects investors' expectations about the announcement. Alternatively, it may capture speculative actions by big investors (daily traders). Other plausible explanations are that investors 
are highly perceptive to news and thus able to react to it early by undertaking correct investment decisions under uncertainty (Heiner [1983]) or they are quite competent despite the complexity of information (Kean and Rosenman [1986]). Regarding (negative) construction announcements on the announcement data, only composite and financial sector returns decline, while there is no reaction to the news on the day of the announcement. However, there is a significant drop in all the returns the day following the release. The services and financial sectors, which are directly related to construction sector activities, react most significantly to the news with about $1.14 \%$ and $1.34 \%$ decline in the returns, respectively.

Positive tourism news raises all the returns, except the industrials sectors, on the day before the announcement. The services sector reacts most significantly, as expected, since tourism is part of this sector. While the news has no impact on the announcement data, the returns for services continue to increase, while the returns for the industrials decline. None of the negative tourism news tends to have any significant effect on any of the stock returns, except the industrial sector and only on the day before the announcement. This may be explained by substitution effect away from services (tourism) sector towards industry if bad news about tourism sector is expected.

Turning to the significance of the non-public information variables in table 2, one observes that the composite and all the sector returns are highly and positively correlated with the world market returns. A $10 \%$ increase in the world market returns raises all returns between $2.9 \%$ and $3.8 \%$. All returns are also affected negatively by the U.S. stock market crash, ranging between $4.77 \%$ and $6.27 \%$. The Russian crisis affects all the returns, except the financials sector, with the biggest impact on the industrials index (1.24\%). As expected, there is no significant impact of the Asian crisis since the main trading and investment partners of Turkey are the European Union countries and the U.S. The earthquake has the most significant effect on all returns, ranging between $3.94 \%$ for the services and $13.89 \%$ for the financials. Finally, the recent banking crisis lower the financials and industrials sector returns by $3.27 \%$ and $4.50 \%$, respectively.

There are also significant day-of-the-week effects in the mean equation. For all shares, Monday returns tend to be relatively lower (compared to Wednesday), whereas Thursday returns are higher. Tuesday returns are relatively lower for the composite returns, while Friday returns are higher for the industrials and services. These results 
are consistent with other findings in the literature on emerging markets. For example, Mills et al. (2000) find significant day-of-the week effects in the Athens Stock Exchange. These results have important implications for modeling stock returns in emerging markets in general.

\section{E. Conditional Variance Equation}

Panel B of table 2 reports the findings for the conditional variance equation. The estimated ARCH coefficients are statistically significant at the 5\% significance level or better. There is a significant asymmetric effect in all cases, as given by the statistically significant and negative asymmetric coefficient, $\gamma$. The estimated coefficient for trading volume is significant in all cases. As expected, higher trading volume is associated with higher volatility. The volume variable enters the variance equation as a percentage change, because level data was found not stationary and using level of volume data might create endogeneity bias. It is well known that including volume in the variance equation may account for ARCH effects; e.g.; Lamoureux and Lastrapes (1990), (1994), and Phylaktis and Kavussanos (1996). In addition, volume may reflect information flow and the inclusion of the volume variable along with other announcement data may yield misleading results. We therefore ran the tests without the volume variable and the results qualitatively stayed the same.

The impact of the CPI announcements on the conditional volatility of the returns is not significant, suggesting that CPI news has only wealth effects and only on the financial sector, as suggested by the results in the mean equation. BOT news raises the market volatility of all returns, but mostly prior to the announcement. Arrival of GDP data releases affects all returns' volatility, except for services, and only on the announcement date. News about the industrial production has no significant effects, while the effects of construction sector news are felt both the day before and after the announcement. Finally, tourism announcements affect the financial sector volatility the day before the announcement and the services sector the day after that.

Overall, except for the CPI and industrial production, all announcements appear to influence market volatility. It is interesting to note that the volatility effects are more significant the day before the announcement, reflecting significant pre-announcement effects. The significance of public information news in the volatility equation is broadly consistent with the evidence for industrial markets reported in 
Jones et al. (1994) and Fleming and Remolona (1999). It appears that their results for industrial countries can be generalized to emerging market economies like Turkey.

There are also significant day-of-the-week effects in the conditional variance equation. Monday and Tuesday seem to be the most important days across all the returns. Monday tends to be associated with relatively higher volatility compared to Wednesday, while Tuesday has a lower level of volatility, suggesting that the volatility is much higher at the fist day of the week.

\section{F. Diagnostic Tests}

Panel C in table 2 reports the diagnostic tests. The estimated Q-statistics suggest that all the estimated models do not suffer from any serial correlation. In addition, the Q-squared tests indicate that the EGARCH $(1,1)$ model captures well the observed time-varying volatility behavior of all stock market returns.

\section{Implications and Conclusions}

This paper has investigated the role of public information arrival in the Turkish stock market. The results reveal some interesting characteristics about market returns and volatility. Regarding returns, except for the financials sector, there is no evidence that nominal returns increase in response to bad inflation news. The financials sector reacts only partially, suggesting that this sector, at best, serves as a partial hedge against inflation, indicating that the real rate of return on stocks is not completely independent of the inflation rate in Turkey. Other announcements from the real sector also affect stock returns, supporting the findings of Melvin and Yin (1998) and Edmonds and Kutan (2002). In addition, the results suggest that public information is reflected in the stock price, providing evidence for the semi-strong form of the efficient market hypothesis.

Evidence also shows that public information arrival significantly affects market volatility. In particular, the market volatility is more sensitive to news about GNP, BOT, tourism and the construction sector, and the reaction is stronger the day before the announcement. It appears that public information affects both returns and volatility by signaling new information that causes investors to re-balance their portfolios. The 
mixture of distributions and recent micro-structure theories relies on information arrival to explain movements in asset returns. Thus, the results have also implications for the practical applicability of these theories in an emerging market such as Turkey.

Overall, public information appears to play a large role in the emerging stock market of Turkey, affecting both returns and volatility. This reflects a combination of three significant changes taking place in the stock market since the late 1980s: greater participation of domestic and foreign investors, increase in the volume of transactions, and the improved transparency of the system. The results cannot be generalized to other emerging markets until more evidence is forthcoming. For example, there appears to be no direct empirical evidence about the significance of public information arrival on financial markets in Greece. Phylaktis and Kavussanos (1996) study the flow of information in the Athens stock exchange, using trading volume as a proxy for information flow. Papapetrou (2001) examines the relationship among oil shocks, stock prices, interest rates and economic activity, while Apergis and Eleftheriou (2002) investigate the link between stock prices, inflation and interest rates. It would be interesting to extend these studies by examining the specific role played by public information arrival in Greek financial markets.

\section{References}

Apergis, N. and Eleftheriou, S. 2002. Interest rates, inflation and stock prices: The case of the Athens stock exchange. Journal of Policy Modeling 3: 231236.

Başci, E.; Özyildirim, S.; and Aydoğan, K. 1996. A note on price-volume dynamics in an emerging stock market. Journal of Banking and Finance 20: 389-400.

Bekaert, G. and Harvey, C. R. 1997. Emerging market volatility. Journal of Financial Economics 4: 29-77

Bollerslev, T. and Wooldridge, J.M. 1992. Quasi-maximum likelihood estimation and inference in dynamic models with time varying covariances. Econometric Reviews 11: 143-172.

Cagan, P. 1974. Common stock values and inflation: The historical record of many countries. National Bureau of Economic Research, Annual Report.

Cai, J.; Cheung,Y.; Lee R. S. K.; and Melvin M.; 2001. Once-in-a-generation Yen volatility in 1998: Fundamentals, intervention, and order flow. Journal of International Money and Finance 20: 327-47.

Choudhry, T. 2001. Inflation and rates of returns on stocks: Evidence from high 
inflation countries. Journal of International Financial Markets, Institutions and Money 11: 75-96.

Clark, P.K. 1973. A subordinate stochastic process model with finite variance for speculative prices. Econometrica 41: 135-155.

Demirer, R. and Karan, M.B. 2002. An investigation of the day-of-the-week effect on stock returns in Turkey. Emerging Markets Finance and Trade 38 (November-December): 47-77.

Edmonds, R. Jr. and Kutan, Ali M. 2002. Is public information really irrelevant in explaining asset returns? Economics Letters 76: 223-229.

Fleming, M.J. and Remolona, E.M. 1999. Price information and liquidity in the U.S. treasury market: The response to public information. Journal of Finance 54: 1901-1915.

Gürsoy, G. and Aydoğan, K. 2002. Equity ownership structure, risk taking, and performance: An empirical investigation of Turkish listed companies. Emerging Markets Finance and Trade 38 (November-December): 5-24.

Güner, N. and Önder, Z. 2002. Information and volatility. Emerging Markets Finance and Trade 38 (November-December): 26-46.

Heiner, R.A. 1983. The origin of predictable behavior. American Economic Review 73 (4): 560-595.

Ito, T.; Lyons, R.; and Melvin M.T.; 1998. Is there private information in the FX market? The Tokyo experiment. Journal of Finance 53: 1111-1130.

Jones, C.M.; Kaul, G.; and Lipson, M. 1994. Information trading and volatility. Journal of Financial Economics 36: 127-154.

Kaen, R. and Rosenman, R.E. 1986. Predictable behavior in financial markets: Some evidence on support of Heiner's hypothesis. American Economic Review 76: 212-220.

Lamoureux, C.G. and Lastrapes, W.D. 1990. Heteroskedasticity in stock return data: Volume versus GARCH effects. Journal of Finance 45: 221-229.

Lamoureux, C.G. and Lastrapes, W.D. 1994. Endogenous trading volume and momentum in stock-return volatility. Journal of Business and Economic Statistics 12: 253-260.

Lyons, R.K. 2001. The micro structure approach to exchange rates. Cambridge (Mass.): MIT Press.

Melvin, M.T. and Yin X. 2000. Public information arrival, exchange rate volatility and quote frequency. Economic Journal 110: 644-61.

Mills, T.C.; Siriopoulos C.; Markellos R.N.; and Harizanis, D. 2000 Seasonality in the Athens stock exchange. Applied Financial Economics 10: 137-142.

Muradoglu, G. 2000. Turkish stock market: Anomalies and profit opportunities. In securities market imperfections in worldwide equity markets. Cambridge University Press. 364-390.

Muradoglu, G.; Berument, H.; and Metin, K. 1999. An empirical investigation of stock returns and determinants of risk in an emerging market: GARCH-M modeling at ISE. Multinational Finance Journal 3: 223-252

Muradoglu, G. and Metin, K. 1996. Efficiency of Turkish stock exchange with 
respect to monetary variables: A cointegration analysis. European Journal of Operational Research 90: 566-576.

O'Hara. M. 1995. Market Microstructure Theory. Cambridge: Blackwell.

Phylaktis, K. and Kavussanos, M.G. 1996. Stock prices and the flow of information in the Athens stock exchange. European Financial Management 2: 113-126.

Papapetrou, E. 2001. Oil price shocks, stock market, economic activity and employment in Greece. Energy Economics 23: 511-532.

Tauchen, G. and Pitts M. 1983. The price variability volume relationship on speculative markets. Econometrica 51: 485-505.

Yüksel, A. 2002. The performance of the Istanbul stock exchange during the Russian crisis. Emerging Markets Finance and Trade 38 (NovemberDecember): 78-102. 